\title{
The effect of Sea urchin (Diadema setosum) gonad extract on IgM and IgG antibodies production in BALB/c mice infected by Salmonella typhi
}

Pengaruh ekstrak gonad Diadema setosum terhadap produksi antibodi IgM dan IgG pada mencit BALB/c yang diinduksi Salmonella typhi

\author{
Wa Ode Salma ${ }^{1}$, Ilyas Yusuf ${ }^{2,3}$, Marni Karo ${ }^{4}$, La Banudi ${ }^{5}$ \\ 'Department of Nutrition, Faculty of Medicine Halu Oleo University, Kendari \\ ${ }^{2}$ Department of Biochemistry, Faculty of Pharmacy Halu Oleo University, Kendari \\ ${ }^{3}$ Department of Immunoserology of Health Analysis, Kendari \\ ${ }^{4}$ Midwifey Program of Medistra Health Higher School, Jakarta \\ ${ }^{5}$ Department of Nutrition, Health Polytechnic, Kendari
}

\begin{abstract}
Background: Salmonella typhi infection decreases of the immune system and influences the adaptive antibodies among malnourished children. The gonad of Diadema setosum (D. setosum) is one of food sources from marine biota that contains high-quality nutrients and potentially can be used as a dietary supplement for typhoid fever condition. Objective: This study aimed to determine the effect of gonad D. setosum extract on the production of antibody $\operatorname{IgM}$ and $\operatorname{IgG}$ in an animal model. Method: This experimental study was used BALB/c mice before and after infected Salmonella typhi through intraperitoneally at $0.2 \mathrm{~mL} x$ the unit $10^{3} \mathrm{CFU} / \mathrm{mL}$. The level of IgM and IgG production was measured by Enzyme Linked Immune Sorbent Assay (ELISA). Experimental animals were divided into 2 groups. The control group was only fed with standard diets, while at the intervention group received the extract of D. setosum gonad in two doses (100 and $200 \mathrm{mg} / \mathrm{kg}$ body weight). Results: Production of IgM antibodies in the control group significantly increased twofold $(p=0.001)$ whereas the intervention group received the extracts of D. setosum gonad $(200 \mathrm{mg} / \mathrm{kg}$ body weight) could suppress the increase in IgM antibody production and indicate the highest increase of IgG antibody significantly $(p<0.05)$ at day 7. Conclusion: The gonad of Diadema setosum extracts $(200 \mathrm{mg} / \mathrm{kg}$ body weight) could suppress the increase in IgM antibody productions and indicate the highest increase of IgG antibody titers in mice infected with Salmonella typhi. The role of anti-microbial substances of the gonad of Diadema setosum, is potential to be utilized as dietary supplement to increase body immune system among patients infected by Salmonella typhi.
\end{abstract}

KEY WORDS: Diadema setosum; gonad; IgM and IgG antibodies; Salmonella typhi

\begin{abstract}
ABSTRAK
Latar belakang: Infeksi Salmonella typhi dapat menurunkan sistem kekebalan tubuh dan mempengaruhi antibodi adaptif pada anak yang kekurangan gizi. Gonad D.setosum merupakan salah satu sumber makanan dari biota laut yang mengandung nutrisi berkualitas tinggi dan berpotensi digunakan sebagai suplemen makanan untuk pasien demam tifoid. Tujuan: Penelitian ini bertujuan untuk mengetahui pengaruh ekstrak gonad D.setosum terhadap produksi antibodi IgM dan IgG model hewan uji. Metode: Penelitian ini menggunakan hewan uji mencit BALB/c sebelum dan sesudah diinfeksi dengan Salmonella typhi melalui intraperitoneal pada $0,2 \mathrm{~mL} \times 10^{3} \mathrm{CFU} / \mathrm{mL}$. Tingkat produksi antibodi IgM dan IgG diukur dengan Enzyme Linked Immune Sorbent Assay (ELISA). Mencit BALB/c dibagi menjadi 2 kelompok yaitu kelompok kontrol hanya diberi makanan standar sedangkan pada kelompok intervensi mendapat tambahan ekstrak gonad D. setosum dalam dua dosis (100 dan $200 \mathrm{mg} / \mathrm{kg}$ berat badan). Hasil: Produksi antibodi IgM pada kelompok kontrol secara signifikan meningkat dua kali lipat $(\mathrm{p}=0,001)$ sedangkan pada kelompok intervensi yang diberi ekstrak gonad D.setosum dengan dosis $200 \mathrm{mg} / \mathrm{kg}$ berat badan dapat menekan peningkatan produksi antibodi IgM dan menunjukkan peningkatan tertinggi antibodi IgG secara signifikan $(\mathrm{p}<0,05)$ pada hari ke-7. Simpulan: Ekstrak gonad D.setosum $(200 \mathrm{mg} / \mathrm{kg}$ berat badan) dapat menekan peningkatan produksi antibodi IgM dan menunjukkan peningkatan antibodi IgG pada
\end{abstract}


tikus yang terinfeksi Salmonella typhi. Aktivitas anti-mikroba dari gonad D.setosum berpotensi dimanfaatkan sebagai suplemen makanan untuk meningkatkan status kekebalan tubuh pada pasien yang terinfeksi Salmonella typhi.

KATA KUNCI: Diadema setosum; gonad; antibodi IgM and IgG; Salmonella typhi

\section{INTRODUCTION}

Typhoid fever is caused by Salmonella typhi, and this infection is still being a health concern in developing countries (1). Indonesia is one of the five countries in Asia that experiences the endemic of typhoid fever (2). The prevalence of this disease is common during the dry season that generally infects children (3-5). Deficiency of nutrient and infectious diseases will suppress immune function (6) by influencing the physical barrier, cellular and antibody production (7). The IgG antibodies production have role in activating other cells to form body immune against viruses and bacteria (8). Acute typhoid infection showed a strong IgM antibody response compared with healthy patients (9). IgM levels were higher in malnutrition than well-nourished childrens (10).

The gonad of Diadema setosum (D. setosum) is one source of food from marine biota that contains high - quality nutrients and is abundance in Indonesia. The amount of vitamin $\mathrm{A}$ and $\mathrm{E}$ are higher compared to the ones found in salmon, sardines, mackerel, cork fish (Chana striata) and eggs, indicate that the gonad of $D$. setosum is sufficient to become a new source of nutrient to boost the immune response (11). In addition, the gonad of D. setosum contains protein, high quality polyunsaturated fatty acids (PUFA) and antioxidant substances (12).

As confirmed in our previous study, BALB/c mice were stimulated by LPS of Salmonella typhi at the control group noticeably shows the significant reduction of body weight at $2,24 \mathrm{~g}(\mathrm{p}=0.001)$, whereas, mice group of intervention with the gonad of $D$. setosum extracts $(200$ $\mathrm{mg} / \mathrm{kg}$ body weight) clearly show the significant increase of $1,7 \mathrm{~g}$ of body weight at days 7 (13). Concerning to this finding, the gonad of $D$. setosum delivers a prospect to be used as a potential food source widely for the reason that it improves nutritional status. It is important that tangible scientific research is conducted to discover the possible health benefits the gonad of D. setosum to adaptive antibodies immune response. This study aims to determine the effect of gonad of D. setosum extract to levels of IgM and IgG antibodies production. This study using animal models of BALB/c mice stimulated by Salmonella typhi bacteria.

\section{METHODS}

\section{The collection of gonad of $D$. setosum}

The gonads of $D$. setosum were collected from Wakatobi National Marine Park, Wakatobi District Southeast Province, Indonesia. The extraction process of $D$. setosum gonads was conducted in Biopharmacy and Phytopharmacy Laboratories, Faculty of Pharmacy, University of Hasanuddin, Makassar, Indonesia. The extraction process was done by using a suitable solvent acetone as described previously (11) and by making two doses (100 and $200 \mathrm{mg} / \mathrm{kg}$ body weight) (13).

\section{Preparation of experimental animals}

Male BALB/c mice of 10 to 12 weeks old, weighing 30-40 $\mathrm{g}$ free of pathogens were obtained from Molecular Biology and Immunology Laboratory for Diseases Infection, Faculty of Medicine, Hasanuddin, Makassar, Indonesia. Mice were reared in a room of proper air circulation and they were maintained in a temperature-controlled facility at $23^{\circ} \mathrm{C}$ and $50 \%$ humidity with $12 \mathrm{~h}$ light/dark cycle and were maintained in cages with care and were cleaned routinely. During rearing, mice were fed with standard natural pellets [the food contained protein (17.5-19.5\%); lipid (3\%); fiber (8\%); ash $(7 \%)$; calcium $(0.9 \%)$; and phosphor $(0.6 \%)$ based on the previous study (13)] and were given aquadest ad libitum. Before of treatment, treated BALB/c mice were preconditioned for two weeks to adapt to the laboratory condition to keep physical and physiological conditions of mice were in a stable state. All experimental procedures for the treatment and maintenance of any laboratory animal were reviewed and approved by the Research Ethics Committee of Medicine Faculty of Hasanuddin 
University as stated in the Recommendation of Research Ethics issued in the registration no. 457/H.8.4.5.31/PP36Kometik/2016.

\section{Experimental procedure and treatment}

After the adaptation period, twelve tail mice $(n=12)$ were then divided into three groups, i.e. group I (control), group II and III (intervention), respectively the first blood sampling of $0.2 \mathrm{~mL}$ was done at tail of each mice at day 0 (baseline), and then all mice were let to rest for 2 hours. After that, the intervention group II and III received the extract of D. setosum gonad in two doses (100 and $200 \mathrm{mg} / \mathrm{kg}$ body weight), whereas those the control group were only fed with standard diets. The second blood respectively sampling of mice was done at day 10 and they were let to rest for 2 hours, and then the three mice groups were infected by Salmonella typhi through intraperitoneally at $\left(0.2 \mathrm{~mL} \times\right.$ the unit $10^{3}$ $\mathrm{CFU} / \mathrm{mL}$ ) based on the previous study (13). Blood of mice were collected at day 5 and day 7 after infected by Salmonella typhi.

\section{Measuring the levels of IgM and IgG serum}

Blood of mice was collected and centrifuged to obtain blood serums. The collected blood serums were kept under the room temperature of $20^{\circ} \mathrm{C}$ before performing the examination of IgM and IgG antibodies titers using Enzyme Linked Immune Sorbent Assay (ELISA) technique. Plasma IgM and IgG antibodies levels were measured using the Rat ELISA Kits (Rat IgM E-25 and Rat IgG E-25G) respectively; ICL, Gentaur, the Netherlands). The use direction of laboratory instruments referred to the information sheets asserted in the KIT. The absorption values of antibody titers were automatically counted by the ELISA reader at a $450 \mathrm{~nm}$ wavelength.

\section{Data analysis}

The investigational results acquired are expressed as the mean \pm standard deviation (SD). One-way ANOVA test was used to determine the statistically significant differences of measurement results of $\operatorname{IgM}$ antibodies whereas IgG antibodies production using dependent $t$-test. Significance was accepted at $\mathrm{p}<0.05$.

\section{RESULTS}

Figure 1, IgM antibody production at baseline and day 10 were not statistically different before infected by Salmonella typhi $(\mathrm{p}>0.05)$ however IgM antibodies production were different after infected by Salmonella typhi $(\mathrm{p}>0.05)$ between the control group and the intervention group. IgM production for the control group significantly increased twofold at days 7 $(\mathrm{p}=0.001)$ compared to the intervention group (100 and $200 \mathrm{mg} / \mathrm{kg}$ body weight). Figure 2, the production of antibody IgG was statistically higher $(p=0.004)$ for the intervention group III ( $200 \mathrm{mg} / \mathrm{kg}$ body weight $)$ compared to the intervention group II ( $100 \mathrm{mg} / \mathrm{kg}$ body weight $)$ and control group.

Our study result indicated at the mice control group, IgM production increased twofold whereas the level of IgG antibodies lower at days 7 compared to that of the intervention group, this shows that failed to

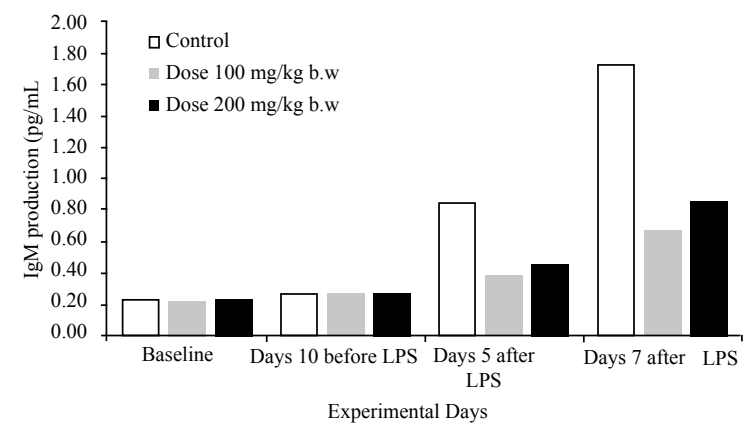

Figure 1. Total of the values of IgM antibody productions are expressed as mean $\pm \mathrm{SD}$. Each group consists of four, 10-12 week old male Balb/C mice $(n=4)$. Results of oneway ANOVA test, significantly $\mathbf{p}<0.05$

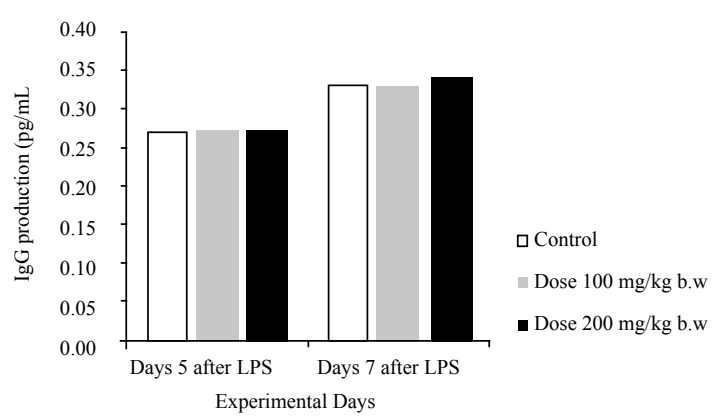

Figure 2. Total of the values of IgG antibody productions are expressed as mean \pm SD. Each group consists of four 10-12 week old male Balb/C mice $(n=4)$. Results of dependent t- test, significantly $\mathbf{p}<0.05$ 
protect them from infection. Conversely the intervention group the gonad of D. setosum extracts $(200 \mathrm{mg} / \mathrm{kg}$ body weight) could suppress the increase in IgM antibody production and indicate the highest increase of IgG antibody significantly at days 7 . The nutrient of gonad of $D$. setosum is likely to have an antimicrobial effect through its role as an antioxidant so it can suppress the bacteria Salmonella typhi.

\section{DISCUSSION}

Antioxidants treatment has the effects and important implications for humoral immunity during infection (14). The high vitamin $\mathrm{A}$ and $\mathrm{E}$ composition in foods have an important role in inducing significant adaptive antibodies and providing protection against infection diseases (15). Vitamin A has an important role in the immune system and sustain the balance of cell function and prevent longer inflammation (16), increased level of IgM and $\mathrm{IgG}$ production in mice infected with tetanus toxoid (17). Vitamin E restores humoral immune function and intracellular cell mediation (18), facilitate in the switching from IgM of IgG antibody production (19).

The level of vitamin E contained in the gonad of D. setosum was $23.47 \mathrm{mg}$ in $100 \mathrm{~g}$ of the gonad and was highest compared to salmon, mackerel, anchovies, sneak head and eggs (11). Interestingly, around $80 \%$ of PUFA was contained in the gonad of D. setosum (12), specifically eicosapentaenoic (EPA) and decoshaexaenoic (DHA) acid (20). Research on human showed that EPA and DHA possess complementary effect to prevent over-inflammation and oxidative stress (21), and can be effective to treat memory disturbance, maintain cognitive function and immune system (22). However, PUFA also has negative effects when it is over-consumed. PUFAs are easily oxidized and combined with free-radicals that can disturb the function of cell membrane (23). There have been much evidence that vitamin $\mathrm{E}$ is capable of protecting easily oxidized chemical substances and maintaining the stability of PUFA in lypo-protein and cell membrane. On the other hand, PUFA is required for transporting vitamin $\mathrm{E}$ to body tissues (24). Deficiency in vitamin $E$ may have detrimental effect on imuno humoral and cell mediation across intra-cellular (18).
The level of vitamin A found in the gonad of $D$. setosum was $1.79 \mathrm{mg}$ for $100 \mathrm{~g}$ of the gonad, which is equal to 2983.93 IU. This level was highest compared to the level of vitamin A found in Salmon, mackerel, anchovies, sneak head and eggs. Moreover, the level of protein reached $1.24 \mathrm{~g}$ for $100 \mathrm{~g}$ of the gonad (11). Intervention of biscuit $(60 \mathrm{~g})$ extracted from the protein of sneak head given to 28 pre-school children (4-5 years old) for 56 days is known to enhance immune respond of IgG antibody (25). Protein is required for transporting vitamin A to the body tissues (26). Deficiency in vitamin A affects humoral respond and may reduce cellular activities and lymphoid organ experiences bad development (27).

The interaction between micro and macro substances plays an important role in protecting and maintaining immune system. It was expected that nutritional interactions contained in the gonad affected immune respond of antibody IgM and IgG. Overall, the nutrients contained in gonad were sufficiently complete to fulfill the requirements as an alternative food resource.

Salmonella typhi can invade wider areas and lead to acute and chronic infections since this microorganism can replicate and protect itself from phagocytosis by epithelial and dendritic cells as well as macrophages in the immune system (28). Low inflammatory responses due to the infection of Salmonella strain lead to persistent infection and facilitate longer survival of pathogens (29). This is affirmed by the proportion of the total typhoid fever patients (193 of 237 patients) noticeably have high value differences between the highest IgM titer $(3200 \mathrm{pg} / \mathrm{mL})$ and the lowest $\operatorname{IgG}$ titer $(200 \mathrm{pg} / \mathrm{mL})$ compared to the IgG antibody value $(400 \mathrm{pg} / \mathrm{mL})$ of normal individuals, as confirmed in a study at a hospital in Kathmandu, Nepal (30).

Higher serum IgG levels but lower IgM antibodies suggesting the late class switching from IgM to IgG in response to the infection well after elimination of pathogen (9). The lag phase IgM has a half-life of about 5 days and to decline before $\operatorname{IgG}$ levels highest in the blood and has a half-life of about 23 days (31). Interestingly, in our study, in BALB/c mice after infected by Salmonella typhi, IgM (lag phase) has a half-life of about 7 days at the intervention group ( $200 \mathrm{mg} / \mathrm{kg}$ body weight). Not yet 
known exactly when the late class switching occurs but the highest increase of $\mathrm{IgG}$ productions compared with the intervention group (100 $\mathrm{mg} / \mathrm{kg}$ body weight) and control groups indicate possibility activation adaptive antibodies immune response after exposure to infected with Salmonella typhi occur at days 7. It is estimated that IgG levels in the intervention group $(200 \mathrm{mg} / \mathrm{kg}$ body weight) will increase again after 7 days.

The activation lymphocytes (antibody production and effector T cell lymphocytes) occur at days 7 and days 14 by the elimination of antigen (8). The cytokine interferon-gamma (IFN-fl) binds to Fc-R results in the switching of IgG subclass that (32). The IgG antibodies have a relatively high affinity and persist in the circulation for a long time (33). The important role of IgG antibodies can also bind to and neutralize bacterial toxins (34). Our study provides new insight on the immune nutrient of the gonad of D.setosum could increase the IgG antibody productions through its role as anti-microbial substances in mice infected with Salmonella typhi.

\section{CONCLUSION}

The gonad of Diadema setosum extracts (200 $\mathrm{mg} / \mathrm{kg}$ body weight) could suppress the increase in IgM antibody productions and indicate the highest increase of IgG antibody titers in mice infected with Salmonella typhi. The role of anti-microbial substances of the gonad of Diadema setosum, is potential to be utilized as dietary supplement to increase body immune status among patients infected by Salmonella typhi.

\section{ACKNOWLEDGMENT}

We thank to Prof. Hatta for valuable discussions (Molecular Biology and Immunology Laboratory for Infection Diseases, Faculty of Medicine, Hasanuddin Makassar, Indonesia). This research was financially supported by the Ministry of Research and Technology, Indonesia.

\section{Conflicts of interests}

The authors declare no conflicts of interest.

\section{REFERENCES}

1. Hatta M, Andi RS, Rob P, Henk LS. New flagellin gene for Salmonella enterica serovar Typhi from the East Indonesian archipelago. Am J Trop Med Hyg 2011;84(3):429-34.

2. Leon RO, Camilo JA, Carolina MDH, Dong B, Sujit KB, Magdarina DA, et al. A study of typhoid fever in five Asian countries: disease burden and implications for controls. Bull World Health Organ 2008;86:260-8.

3. Karkey A, Thompson CN, Thieu NTV, Dongol S, Phuong TLT, Vinh PV, et al. Differential epidemiology of Salmonella Typhi and Paratyphi A in Kathmandu, Nepal: a matched case control investigation in a highly endemic enteric fever setting. PLoS Negl Trop Dis 2013;7(8):e2391.

4. Charles RC, Sultana T, Alam MM, Yu Y, Wu FY, Bufano MK, et al. Identification of immunogenic Salmonella enterica serotype Typhi antigens expressed in chronic biliary carriers of S. Typhi in Kathmandu, Nepal. PLoS Neg1 Trop Dis 2013;7(8):e2335.

5. Crump JA, Mintz ED. Global trends in typhoid and paratyphoid fever. Clin Infect Dis 2010;50:241-6.

6. Mora JR, Iwata M, Von Andrian UH. Vitamin effects on the immune system: vitamins $\mathrm{A}$ and $\mathrm{D}$ take centre stage. Nat Rev Immunol 2008;8:685-98.

7. Wintergerst ES, Maggini, Hornig DH. Contribution of selected vitamins and trace elements to immune function. Ann Nutr Metab 2007;51:301-23.

8. Abbas AK, Licthman AH, Pillai S. Cellular and molecular immunology. Eighth Edition. Philadelphia: Elsevier Saunders; 2015.

9. Liang L, Juarez S, Nga TV, Dunstan S, Nakajima SR, Davies DH, et al. Immune profiling with a Salmonella Typhi antigen microarray identifies new diagnostic biomarkers of human typhoid. Sci Rep 2013;3:1043.

10. Rytter MJH, Kolte L, Briend A, Friis H, Christensen BV. The immune system in children with malnutrition-a systematic review. PLoS One 2014;9:e105017.

11. Salma WO, Wahyuni S, Yusuf I, Yasir-Haya LM, Irawan Y, As'ad S. Immune nutrient content of Sea urchin (Diadema setosum) gonads. International Journal of Nutrition and Food Sciences 2016;5(5):330-6.

12. Chen G, Xiang WZ, Lau CC, Peng J, Qiu JW, Chen F, et al. Comparative analysis of lipid and carotenoid composition of the gonads of Anthocidaris crassispina, Diadema setosum and Salmacis sphaeroides. Food Chem 2010;120:973-7.

13. Salma WO, Hafizah I, Nurtamin T, Haya LOMY, As'ad S. The potential gonad of Diadema setosum as a healthy food to improve the nutritional status of coastal's children. Int J Sci Basic Appl Research 2016;27(2):189-95.

14. Crump EK, Langston PK, Rajkarnikar S, Grayson MJ. Antioxidant treatment regulates the humoral 
immune response during acute viral infection. J Virol 2013;87(5):2577-86.

15. Patel S, Faraj Y, Duso KD, Reiley WW, Karlsson AE, Cherry SS, et al. Comparative safety and efficacy profile of a novel oil in water vaccine adjuvant comprising vitamins $\mathrm{A}$ and $\mathrm{E}$ and a catechin in protective antiinfluenza immunity. Nutrients 2017;9(5):E516.

16. Ross AC. Vitamin A and retinoic acid in T cell-related immunity. Am J Clin Nutr 2012;96:1166S-72S.

17. Tan L, Wray AE, Ross AC. Oral vitamin A and retinoic acid supplementation stimulates antibody production and splenic Stra6 expression in tetanus toxoid-immunized mice. J Nutr 2012;142(8):1590-5

18. Wu D, Meydani SN. Age-associated changes in immune and inflammatory responses: impact of vitamin $\mathrm{E}$ intervention. J Leukoc Biol 2008;84:900-14.

19. Tanaka J, Fujiwara H, Tonsu M. Vitamin E and immune response: I. Enhancement of helper T cell activity by dietary supplementation of vitamin $\mathrm{E}$ in mice. Immunology 1979;38(4):727-34.

20. Delianis P, Ana A, Indriatmoko, Sri S, Dwi H. The potency of sea urchin (Diadema setosum) gonad on brain cells of white rats (Rattus norvegicus). Asian J Pharm 2016;10(2):100-7.

21. Mozaffarian D, Wu JH. (n-3) fatty acids and cardiovascular health: are effects of EPA and DHA shared or complementary?. J Nutr 2012;142(3):614S$25 \mathrm{~S}$.

22. Molfino A, Gioia G, Fanelli FR, Muscaritoli M. The role for dietary omega-3 fatty acids supplementation in older adults. J Nutr 2014;6(10):4058-72.

23. Tao L. Oxidation of polyunsaturated fatty acids and its impact on food quality and human health. Adv Food Technol Nutr Sci Open J 2015;1(6):135-42.
24. Jim M, Stewart TA. Essestials of human nutrition, fourth edition. USA: Oxford University Press; 2012.

25. Sari DK, Marliyati SA, Kustiyah L, Khomsan A. Role of biscuits enriched with albumin protein from snakehead fish, zinc and iron on immune response of under five children. Pak J Nutr 2014;13(1):28-32.

26. Kawaguchi R, Zhong M, Kassai M, Ter-Stepanian M, Sun H. Vitamin A transport mechanism of the multitransmembrane cell-surface receptor STRA6. Membranes 2015;5(3):425-53.

27. Bono MR, Tejon G, Flores-Santibañez F, Fernandez D, Rosemblatt M, Sauma D. Retinoic acid as a modulator of T cell immunity. Nutrients 2016;8(6):E349.

28. Gunn JS, Marshall JM, Baker S, Dongol S, Charles RC, Ryan ET. Salmonella chonic carriage: epidemiology diagnosis, and gallbladder persistence. Trends Microbiol 2014;22(11):648-55.

29. Merrell DS, Falkow S. Frontal and stealth attack strategies in microbial pathogenesis. Nature 2004;430:250-6.

30. Anurag A, Ramanuj R, Pramod PR, Krishna DM, Birendra PG. Evaluation of sensitivity and specificity of ELISA against Widal test for typhoid diagnosis in endemic population of Kathmandu. BMC Infect Dis 2015;15:523.

31. Abbas AK, Licthman AH, Pillai S. Cellular and molecular immunology, 7th Edition. Philadelphia: Elsevier Saunders; 2012.

32. Schroder K, Hertzog PJ, Ravasi T, Hume DA. Interferon gamma: an overview of signals mechanism and functions. J Leukoc Biol 2004;75(2):163-89.

33. Meulenbroek AJ. Human IgG subclasses: useful diagnostic markers for immunocompetence, Third Edition. Amsterdam: Sanquin the Netherlands; 2008.

34. Peakman M, Vergani D. Basic and clinical immunology, 2nd Edition. London: Elsevier Health Sciences; 2009. 